\title{
A Study to Assess the Attitude of Medical Students towards Learning Communication Skills in a Teaching Hospital in Kerala
}

\author{
V. K. Sreelatha ${ }^{1}$, V. D. Manjula ${ }^{2}$ \\ ${ }^{1}$ Department of ENT, Government Medical College, Ernakulam, Kerala. \\ ${ }^{2}$ Department of Community Medicine, Government Medical College, Ernakulam, Kerala.
}

\section{ABSTRACT}

\section{BACKGROUND}

Communication plays a crucial role in the present era of medical litigations and hospital attacks. A good doctor has to be a good communicator. $80 \%$ of medical errors are due to communication failure as reported in a study. The need for improving the medical communication skills of health professionals is getting recognized. The use of structured programme of effective and formal communication skills training is the need of the hour. In order to improve communication skills, Medical council of India (MCI) has launched the ATECOM (attitude, ethics and communication) module in the MBBS curriculum from 2019. The purpose of this study was to assess the attitude of medical students towards learning communication skills.

\section{METHODS}

A total of 447 students from 7 batches were enrolled in the study. All students were asked to fill up the communication skills attitude scale (CSAS) questionnaire which consists of 13 positive attitude questions and 13 negative attitude questions which was scored in Likert's scale. The data was analysed using Statistical Package for Social Sciences (SPSS).

\section{RESULTS}

There were a total of 447 students, of which 128 were males and 319 were females. The mean total score for positive attitude was 54.19 (SD - 5.99) and the mean score for negative attitude was 33.42 (SD - 5.27). The mean positive attitude score was more for females (54.61; SD - 5.82) than males (53.15; SD - 6.28) and the difference was statistically significant. The female students had a lesser mean negative attitude score compared to males. Batch wise analysis was done using analysis of variance (ANOVA). The P value for total positive score between batches was 0.001 and for total negative score was 0.28 .

\section{CONCLUSION}

The study showed an overall positive attitude to learning communication skills with girls showing a more positive attitude and less negative attitude than boys.

\section{KEY WORDS}

Attitude, Communication skills, Medical Students, Competency
Corresponding Author:

Dr. V.D. Manjula,

Department of Community Medicine,

Government Medical College,

Ernakulam, Kerala.

E-mail:vdmanju@gmail.com

DOI: 10.14260/jemds/2021/673

How to Cite This Article:

Sreelatha VK, Manjula VD. A study to assess the attitude of medical students towards learning communication skills in a teaching hospital in Kerala. J Evolution Med Dent Sci 2021;10(38):3317-3321, DOI: 10.14260/jemds/2021/673

Submission 28-07-2021,

Peer Review 04-09-2021,

Acceptance 11-09-2021,

Published 20-09-2021.

Copyright (C) 2021 V. K. Sreelatha et al. This is an open access article distributed under Creative Commons Attribution License [Attribution 4.0 International (CC BY 4.0)] 


\section{BACKGROUND}

Communication plays a crucial role in the present era of medical litigations and hospital attacks. An ideal doctor should have a mixture of aptitudes so that he is able to carry out the range of services in health settings which is relevant, cost effective and is of good quality. This was the concept of the Five-star doctor proposed by World Health Organization (WHO). The five qualities attributed are that of care giver, decision maker, communicator, community leader and manager. ${ }^{1}$ Effective doctor patient communication is an important part of patient care and a crucial basic skill for doctors that cannot be delegated. ${ }^{3}$

Three different purposes of doctor patient communication are to build a good interpersonal relationship, exchanging information and taking treatment decisions. ${ }^{4}$ The ability to communicate is one of the key skills needed for a doctor in addition to other skills such as intellectual skills, conceptual skills and observational skills. If the attending physician fails to address the queries, expectations and concern of patient and relatives, can lead to dissatisfaction. This may be one of the reasons for the increase in hospital attacks and assault on the doctors. ${ }^{5}$

Majority of complaints against doctors are due to communication problems rather than clinical competence and this in turn can lead to malpractice allegations. ${ }^{6}$

Good communication is the key to improving the efficiency of health care systems, patient satisfaction and reducing the number of malpractice complaints. ${ }^{7}$ Communication skills play a significant role in clinical capability and it also affects patient compliance, understanding and satisfaction. ${ }^{4}$ Medical education curriculum in India used to focus mainly on the clinical skills of the medical student. But certain other skills called the nontechnical skills like communication skills, interpersonal and managerial skills are needed to work as a team and to deal with the patient ${ }^{105}$. The concept of communication as a bedside manner or history taking has changed to considering communication skill as a measurable clinical skill which can be taught. ${ }^{8}$

Changes in people's behaviour can be brought about by changes in attitude and measuring attitudes plays an important role in analysing behavior. ${ }^{9}$ Measuring medical student's attitude is important in planning educational programs and experiences that aid in enhancing these skills 4 and they also form a crucial outcome measure for curricular interventions. ${ }^{10}$ Medical student's attitude towards communication skills training may be an important indicator of importance they give to it and may eventually influence communication behaviour in clinical settings. ${ }^{11}$

All throughout the world, the importance of improving the medical communication skills of the health professionals is getting recognized and more attention is now being given to communication skills training. Knowledge, problem solving and physical examination skills are often wasted in the absence of good communication skills. ${ }^{12}$

The use of structured programme of effective and formal communication skills, training and assessment is the need of the hour in the present era of medical litigations and hospital attacks. Good communication skill is being included as a competency in the new competency based medical education curriculum. This is achieved by including the ATECOM module in the MBBS curriculum from 2019.
This study was done to assess the attitude of medical students towards learning communication skills using a widely used and validated 26 item communication skill attitude scale developed by Rees and Sheard..$^{13}$ The attitude of medical students plays a major role in moulding their future as good doctors.

\section{METHODS}

This cross-sectional study was done at Government Medical College, Ernakulam in Central Kerala, India after obtaining clearance from Institutional Ethics Committee. This was done from July 2018 to December 2018. It was a census method where all study subjects in the institution who gave the consent, a total of 447 students from seven batches were enrolled. All students were asked to answer the CSAS questionnaire after getting informed consent.

This study was done to assess the attitude of medical students towards learning communication skills using a widely used and validated 26 item communication skill attitude scale developed by Rees and Sheard. The CSAS was developed to explore the attitudes of medical students toward learning of communication skills. ${ }^{13}$ It consists of 26 items which assesses the perception of students of how communication skills are taught, the significance of good communication skills to do well in exams and become a good doctor, and how communication skills can be employed to show respect to patients. Based on initial psychometric analysis by Rees et al. 20 two subscales were recognized which constitutes positive and negative attitudes. Both subscales had good reliability and internal consistency in this study.

The items 1, 4, 5, 7, 9, 10, 12, 14, 16, 17, 21, 23 and 25 indicates positive attitudes toward studying communication skills, for example item 5 ("Learning communication skills has helped or will help me respect patients"). The items: 2,3 , $6,8,11,13,15,18,19,20,22,24$ and 26 are included in the negative attitude scale towards studying communication skills, for example item no 6 ("I haven't got time to learn communication skills")

A five-point Likert sale was used to record responses for all 26 items. Positive attitude questions were scored with 5 points for strongly agree, 4 for agree, 3 for neutral, 2 for disagree and 1 for strongly disagree. The negative attitude questions were scored in reverse order, 5 points for strongly disagree, 4 for disagree, 3 for neutral, 2 for agree and 1 for strongly agree and one point for strongly agree. Scores for both positive and negative attitude scales were calculated by adding up the points scored for the 13 items of each subscale. Each score ranged from 13 to 65 with higher scores reflecting stronger attitude.

\section{Data Analysis}

Analysis of the data was done using SPSS software. Reliability of the tool was ascertained by calculating internal consistency using Cronbach's alpha. Scores among subgroups was tested using t-test and ANOVA. A P value of less than or equal to 0.05 was considered significant. 


\section{RESULTS}

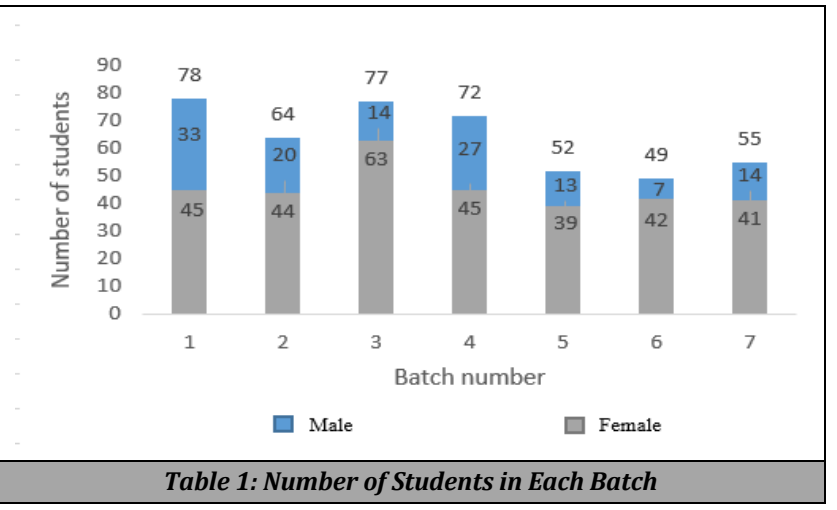

A total of 447 students were enrolled in the study, out of which 128 were males and 319 were females. The students from first year to final year and two batches of house surgeons, one batch who had just started internship and second batch who was about to finish internship were also included accounting to a total of 7 batches. Maximum number of students were from the first year (78) and least from batch 6 who has just started internship (49) (Table 1)

The reliability of the tool was tested using Cronbach's alpha which was 0.83 for positive attitude scale and 0.60 for negative attitude. This shows good internal consistency for the positive attitude scale.

The mean of total positive score was 54.19 with standard deviation of 5.99 and mean of total negative scores was 33.42 with standard deviation 5.27. The higher positive score shows that the students have an overall positive attitude to learning communication skills.

The mean scores for positive attitude was compared between males and females by $t$ test and showed a $P$ value of 0.019 which was statistically significant. But the $P$ value for negative attitude scores was 0.381 which was not significant (Table 2).

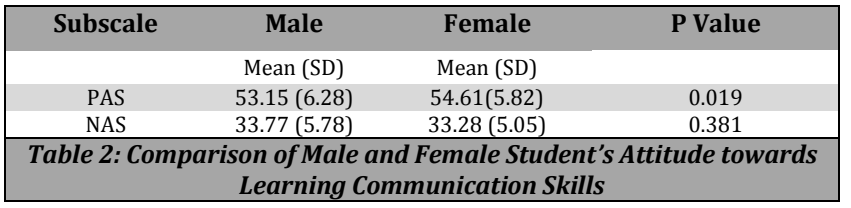

In the positive attitude scale (PAS), means range between 3.45 (item 12: Learning communication skills is fun.) and 4.83 (item 1: In order to be a good doctor, I must have good communication skills), and in negative attitude scale (NAS), means range between 1.86 (item 19: I don't need good communication skills to be a doctor) and 3.1 (item 18: When applying for medicine, I thought it was a really good idea to learn communication skills) (Table 3).

Batch wise analysis was done using ANOVA (Table 4). This was done to assess whether there is any change in attitude during the course of the study. In this, final year MBBS (Batch Number 5) students had the highest positive attitude score and the lowest negative attitude score. The first year MBBS students had the lowest positive attitude score (Batch number 1). The highest negative attitude score was seen in the batch which have just started internship (Batch 6). The P value for positive attitude scores was 0.001 which was statistically significant. The $\mathrm{P}$ value for negative attitude score was 0.284

\begin{tabular}{|c|c|c|}
\hline $\begin{array}{l}Q \\
\text { no }\end{array}$ & Positive Attitude Questions & $\begin{array}{l}\text { Mean } \\
\text { (SD) }\end{array}$ \\
\hline 1 & $\begin{array}{l}\text { In order to be a good doctor, I must have good communication } \\
\text { skills. }\end{array}$ & $\begin{array}{c}4.83 \\
(0.42)\end{array}$ \\
\hline 4 & $\begin{array}{l}\text { Developing my communication skills is just as important as } \\
\text { developing my knowledge of medicine. }\end{array}$ & $\begin{array}{c}4.36 \\
(0.75)\end{array}$ \\
\hline 5 & $\begin{array}{l}\text { Learning communication skills has helped or will help me } \\
\text { respect patients. }\end{array}$ & $4.4(0.75)$ \\
\hline 7 & Learning communication skills is interesting. & $\begin{array}{c}3.79 \\
(0.99)\end{array}$ \\
\hline 9. & $\begin{array}{l}\text { Learning communication skills has helped or will help } \\
\text { facilitate my team working skills }\end{array}$ & $\begin{array}{c}4.39 \\
(0.66)\end{array}$ \\
\hline 10 & $\begin{array}{l}\text { Learning communication skills has improved my ability to } \\
\text { communicate with patients. }\end{array}$ & $\begin{array}{c}4.33 \\
(0.72)\end{array}$ \\
\hline 12 & Learning communication skills is fun. & $\begin{array}{c}3.45 \\
(1.05)\end{array}$ \\
\hline 14 & $\begin{array}{l}\text { Learning communication skills has helped or will help me } \\
\text { respect my colleagues. }\end{array}$ & $\begin{array}{c}4.18 \\
(0.82)\end{array}$ \\
\hline 16. & $\begin{array}{l}\text { Learning communication skills has helped or will help me } \\
\text { recognize patient's rights regarding confidentiality and } \\
\text { informed consent }\end{array}$ & $4.23(0.7)$ \\
\hline 17 & $\begin{array}{l}\text { Communication skills teaching would have a better image if it } \\
\text { sounded more like a science subject. }\end{array}$ & $\begin{array}{c}3.75 \\
(1.04)\end{array}$ \\
\hline 21 & $\begin{array}{l}\text { I think it's really useful learning communication skills on the } \\
\text { medical degree }\end{array}$ & $\begin{array}{c}4.22 \\
(0.78)\end{array}$ \\
\hline 23 & $\begin{array}{l}\text { Learning communication skills is applicable to learning } \\
\text { medicine. }\end{array}$ & $\begin{array}{c}3.89 \\
(0.83)\end{array}$ \\
\hline 25 & $\begin{array}{l}\text { Learning communication skills is important because my } \\
\text { ability to communicate is a lifelong skill. } \\
\text { Negative attitude questions }\end{array}$ & $\begin{array}{c}4.36 \\
(0.71)\end{array}$ \\
\hline 2 & I can't see the point in learning communication skills & $\begin{array}{c}1.77 \\
(0.81)\end{array}$ \\
\hline 3 & $\begin{array}{l}\text { Nobody is going to fail their medical degree for having poor } \\
\text { communication skills. }\end{array}$ & $2.76(1.1)$ \\
\hline 6 & I haven't got time to learn communication skills. & $\begin{array}{c}2.77 \\
(1.01)\end{array}$ \\
\hline 8 & $\begin{array}{l}\text { I can't be bothered to turn up to sessions on communication } \\
\text { skills. }\end{array}$ & $\begin{array}{c}2.67 \\
(0.97)\end{array}$ \\
\hline 11 & $\begin{array}{l}\text { Communication skills teaching states the obvious and then } \\
\text { complicates it. }\end{array}$ & $\begin{array}{c}2.87 \\
(0.91)\end{array}$ \\
\hline 13 & Learning communication skills is too easy. & $\begin{array}{c}2.89 \\
(0.95)\end{array}$ \\
\hline 15 & $\begin{array}{l}\text { I find it difficult to trust information about communication } \\
\text { skills given to me by non-clinical lecturers. }\end{array}$ & $\begin{array}{c}2.55 \\
(0.93)\end{array}$ \\
\hline 18 & $\begin{array}{l}\text { When applying for medicine, I thought it was a really good } \\
\text { idea to learn communication skills. }\end{array}$ & $3.1(1.1)$ \\
\hline 19 & I don't need good communication skills to be a doctor. & $1.7(0.84)$ \\
\hline 20 & $\begin{array}{l}\text { I find it hard to admit to having some problems with my } \\
\text { communication skills. }\end{array}$ & $2.83(0.98)$ \\
\hline 22 & $\begin{array}{l}\text { My ability to pass exams will get me through medical school } \\
\text { rather than my ability to communicate. }\end{array}$ & $\begin{array}{c}3.02 \\
(1.08)\end{array}$ \\
\hline 24 & $\begin{array}{l}\text { I find it difficult to take communication skills learning } \\
\text { seriously. }\end{array}$ & $\begin{array}{c}2.75 \\
(1.01)\end{array}$ \\
\hline 26 & $\begin{array}{l}\text { Communication skills learning should be left to psychology } \\
\text { students, not medical students. }\end{array}$ & $\begin{array}{c}1.73 \\
(0.82)\end{array}$ \\
\hline
\end{tabular}

\begin{tabular}{|c|c|c|c|c|c|c|}
\hline \multirow[b]{2}{*}{ Batch } & \multicolumn{3}{|c|}{ Positive Attitude Scores } & \multicolumn{3}{|c|}{ Negative Attitude Scores } \\
\hline & $\begin{array}{c}\text { Median } \\
\text { (IQR) }\end{array}$ & $\begin{array}{c}\text { Mean } \\
\text { (SD) }\end{array}$ & $\begin{array}{c}P \\
\text { Value }\end{array}$ & $\begin{array}{c}\text { Median } \\
\text { (IQR) }\end{array}$ & $\begin{array}{c}\text { Mean } \\
\text { (SD) }\end{array}$ & $\begin{array}{c}P \\
\text { Value }\end{array}$ \\
\hline 1 & $51(9)$ & $\begin{array}{l}52.03 \\
(6.58)\end{array}$ & \multirow{7}{*}{0.001} & $33(7)$ & $\begin{array}{l}33.67 \\
(5.87)\end{array}$ & \multirow{7}{*}{0.284} \\
\hline 2 & $57(6.8)$ & $\begin{array}{l}55.58 \\
(6.22)\end{array}$ & & $32(6.8)$ & $\begin{array}{l}33.11 \\
(6.07)\end{array}$ & \\
\hline 3 & $54(9)$ & $\begin{array}{l}54.96 \\
(5.31)\end{array}$ & & $33(6)$ & $\begin{array}{l}33.80 \\
(4.76)\end{array}$ & \\
\hline 4 & $55(7.5)$ & $\begin{array}{l}55.19 \\
(5.06)\end{array}$ & & $33(4.8)$ & $\begin{array}{l}33.59 \\
(4.34)\end{array}$ & \\
\hline 5 & $55(9)$ & $\begin{array}{l}55.63 \\
(5.29)\end{array}$ & & $32(5.8)$ & $\begin{array}{l}31.80 \\
(6.09)\end{array}$ & \\
\hline 6 & $53(10.5)$ & $\begin{array}{l}52.81 \\
(6.77)\end{array}$ & & $35(6.5)$ & $\begin{array}{c}34.39 \\
(4.82)\end{array}$ & \\
\hline 7 & $52(8)$ & $\begin{array}{l}53.13 \\
(5.68)\end{array}$ & & $34(6)$ & $\begin{array}{l}33.33 \\
(4.59)\end{array}$ & \\
\hline \multicolumn{7}{|c|}{ Table 4: Batch Wise Analysis (ANOVA) } \\
\hline
\end{tabular}

\section{DISCUSSION}

This cross-sectional study assessed the attitude towards learning communication skills among medical students from first year to the completion of internship. Cronbach's alpha was used to calculate the reliability coefficient for each sub 
scale. Rees C, Sheard C, Davies S has calculated 0.87 for PAS and 0.80 for NAS, 10 Cronbach's alpha were 0.90 for PAS and 0.65 for NAS in a study from Turkey ${ }^{14}$ and 0.90 for PAS and 0.68 in an Iranian study. ${ }^{15}$ In our study the values were 0.83 and 0.60 for PAS and NAS respectively. This was indicative of good internal consistency.

In our study, the mean of total positive attitude score was $54.19 \pm 5.99$ and mean of total negative score was $33.42 \pm$ 5.27 which means that there is an overall positive response to learning communication skills. This was similar to a study conducted in Saudi Arabia. ${ }^{16}$ The student's attitude to learning communication skills influences various factors like the time that they will spend for learning these skills and how they will apply it in their clinical practice. ${ }^{17}$

In our study, girl students were having higher positive scores than males which was statistically significant, but male students having higher negative scores was not statistically significant. But in a study conducted at Saudi Arabia, higher positive scores of female students was not statistically significant but the higher negative scores among male students was significant. ${ }^{16}$ Similar results were also obtained in various multicentre studies. ${ }^{10,18}$ A study conducted in Iran ${ }^{15}$ also showed a more positive attitude to learning communication skills in girl students compared to boys. This may point to a fact that universally, female students are having more positive attitude than male students. This may be due to more open nature of females towards information giving and building rapport compared to males. ${ }^{18}$ This study also emphasised the need for making the male students aware of the importance of communication skills. Changes in attitude can bring about changes in behaviour. It is important that these students must not belittle the importance of communication skills. ${ }^{18}$ But in a study conducted in Nepal, ${ }^{19}$ the $\mathrm{P}$ value for positive attitude scale was not statistically significant.

Batchwise analysis done in our college showed highest positive score and lowest negative score in final year students. Studies done in Chitwan Medical College, Nepal ${ }^{19}$ and one done in Taif University, Saudi Arabia ${ }^{16}$ also showed that the final year medical students had highest positive score and lowest negative score. In another study, fourth year medical students had more positive attitude than first years. ${ }^{20}$ All these results point to the fact that the students realise the importance of learning communication skills over the years.

One negative factor we noticed in our study was that the first year MBBS students had the lowest positive attitude score. This implies that some measures must be taken to ensure that they understand the importance of communication skills. Our results are in contrast to the results of a study done at University of Aberdeen, Scotland and it showed significantly higher positive scores for first year students compared to $2^{\text {nd }}$ and $3^{\text {rd }}$ years. ${ }^{21}$

\section{CONCLUSIONS}

This study showed an overall better total positive attitude score than the negative attitude score among students. Female students had more positive attitude than male students. It is vital that students have a positive attitude to learning communication skills because this influences various factors like the time that they will spend for learning these skills and how they will apply it in their clinical practice. Various studies also show that universally, male students are having a lower positive attitude towards learning communication skills. Such negative attitudes can make the students less interested in learning communication skills. Communication skills were not routinely taught in Indian medical schools. A structured programme for the improvement in communication skills is the need of the hour. The ATECOM module in the new MBBS curriculum is supposed to bring about changes in the attitude of medical students. Let us hope that the new Indian medical graduates understand the importance of good communication and are able to communicate well with the patient and be a better doctor as conceptualized by World Health Organisation.

\section{Limitations of the Study}

The study was done at a single medical college and it may not represent the whole medical student community. As the students from $2^{\text {nd }}$ year to house surgeons do not have an exposure to communication skills training, they may not be able to understand the relevance of communication skills.

Conflict of interest: None

Data sharing statement provided by the authors is available with the full text of this article at jemds.com.

Financial or other competing interests: None.

Disclosure forms provided by the authors are available with the full text of this article at jemds.com.

The support staff of labour room and cardiac ICU.

\section{REFERENCES}

[1] Boelen C. Frontline doctors of tomorrow. World Health 1994;47:4-5.

[2] Beck RS, Daughtridge R, Sloane PD. Physician-patient communication in the primary care office: a systematic review. The Journal of the American Board of Family Practice 2002;15(1):25-38.

[3] Simpson M, Buckman R, Stewart M, et al. Doctor-patient communication the Toronto consensus statement. Brit Med J 1991;303(6814):1385-7.

[4] Ong LM, de Haes JC, Hoos AM, et al. Doctor-patient communication: a review of the literature. Social Science \& Medicine 1995;40(7):903-18.

[5] Arneja I, Lal P. Communications skills training- a missing link in medical education curriculum. MAMC J Med Sci 2017;3(3):117-9.

[6] Silverman J, Kurtz SM, Draper J, et al. Skills for communicating with patients. $2^{\text {nd }}$ edn. Abingdon, Oxon, United Kingdom (UK): Radcliffe Medical Press 1998.

[7] Beckman HB, Markakis KM, Suchman AL, et al. The doctor-patient relationship and malpractice. Lessons from plantiff depositions. Arch Int Med 1994;154(12):1365-70.

[8] Makoul G. MSJAMA. Communication skills education in medical school and beyond. JAMA 2003;289(1):93.

[9] Petty RE, Wegener DT, Fabrigar LR. Attitudes and attitude change. Annu Rev Psychol 1997;48:609-47. 
[10] Rees C, Sheard C. The relationship between medical students' attitudes towards communication skills learning and their demographic and education-related characteristics. Med Edu 2002;36(11):1017-27.

[11] Languille DB, Kaufman DM, Laidlaw TA, et al. Faculty attitudes toward medical communication and their perceptions of students' communication skills training at Dalhousie University. Med Educ 2001;35(6):548-54.

[12] Kurtz S, Silverman J, Draper J. Teaching and learning communication skills in medicine. Oxford: Radcliffe Medical Press 1998.

[13] Rees C, Sheard C, Davies S. The development of a scale to measure medica students' attitudes towards communication skills learning: the Communication Skills Attitude Scale (CSAS). Med Educ 2002;36(2):141-7.

[14] Harlak H, Dereboy C, Gemalmaz A. Validation of a Turkish translation of the communication skills attitude scale with Turkish medical students. Education for Health (Abingdon, England) 2008;21(1):55.

[15] Fazel l, Aghamolaei T. Attitudes toward learning communication skills among medical students of a University in Iran. Acta Medica Iranica 2011;49(9):6259.
[16] Alotaibi FS, Alsaeedi A. Attitudes of medical students toward communication skills learning in Western Saudi Arabia. Saudi Medical Journal 2016;37(7):791-5.

[17] Dornan T, David T. Adult learning and continuing education. Diabet Med 2000;17(1):78-86.

[18] Lumma-Sellenthin A. Students' attitudes towards learning communication skills: correlating attitudes, demographic and metacognitive variables. International Journal of Medical Education 2012;3:201-8.

[19] Piryani S, Piryani RM, Deo GP. Medical students' attitudes toward communication skills learning in Chitwan Medical College, Nepal. Journal of BP Koirala Institute of Health Sciences 2020;3(1):96-104.

[20] Wright KB, Bylund C, Ware J, et al. Medical student attitudes toward communication skills training and knowledge of appropriate provider-patient communication: a comparison of first-year and fourthyear medical students. Medical Education Online 2006;11(1):4594.

[21] Cleland J, Foster K, Moffat M. Undergraduate students' attitudes to communication skills learning differ depending on year of study and gender. Med Teach 2005;27(3):246-51. 